\title{
Wetenskapsteorie, eksegetiese metodologie en Ou Testament teologie
}

\author{
MG Swanepoel \\ Universiteit van die Noorde
}

\begin{abstract}
Epistemology, exegetic methodology and Old Testament theology
\end{abstract}

Scientific and theological statements are deeply rooted in the socio-cultural context of the individual researcher. Different exegetical methods must be evaluated each according to its epistemological paradigm. Historical and structural elements in biblical texts should not be seen in terms of a clash between historical and structural paradigms. Exegetical methodology of the Old Testament is entering a post-critical phase which has implications for the diversity of Old Testament texts and theologies. Historical understanding bridges the gap between today, Word and event respectively by means of a horizon convergence and forms part of a holistic approach. The Old Testament theology cannot achieve its task, for today, without the interchange between text, exegetical method and scientific theory.

\section{UITGANGSPUNT}

Die vraag na die aard en werklikheidsgehalte van wetenskaplike kennis word wêreldwyd vir Bybelwetenskaplikes toenemend belangrik. Wetenskapsteorie as epistemologiese en ontologiese besinning oor die resultate van wetenskaplike ondersoek kan daarom nie geïgnoreer word nie. Rossouw (1980: 7) beklemtoon tereg in hierdie verband dat teoretiese vooronderstellinge van een of ander aard nie slegs waarneminge moontlik maak nie, maar ook determineer wat waargeneem word. Hermeneutiek in aansluiting by wetenskapsteorie is die wetenskaplike nadenke oor die weg waarlangs verstaan, geken en waargeneem word. Die eksegeet, sy eksegetiese metode tesame met die onderliggende wetenskapsteorie en die 
Ou-Testamentiese teks is medebepalend in die daarstel van 'n Ou Testament teologie waaruit ons God se woorde en handelinge met mense in samehang kan sien. Ou Testament teologie behels vir my die eksegetiese verstaan en blootlegging van die diverse teologiese boodskap(pe) van die verskillende Ou-Testamentiese tekste/ blokke/boeke met die oog op vandag.

\section{WETENSKAPSTEORETIESE VRAE}

Die hermeneutiese probleem het sy Sitz im Leben, volgens Rossouw (1980: 18) binne die konteks van die mislukkende kommunikasieproses. Die ervaring waarin hierdie probleem sy oorsprong het kan die hermeneutiese ervaring genoem word. Volgens hom kan die hermeneutiese probleem alleen prakties opgelos word deur ' $n$ bewuste verstaanspoging van daadwerklike interpretasie. Die probleem waarmee die hermeneutiek te kampe het, is die kloof (Pannenberg 1967: 91) tussen die gebeure wat aanleiding gegee het tot die ontstaan van die teks en die skriftelike neerslag van die teks wat ons voor ons het enersyds, maar ook andersyds tussen toe (die denkwêreld van destyds) en vandag (die wetenskapteoretiese vertrekpunt van die eksegeet).

Lategan (1985: 3) wys op die belangrike rol wat filosofiese kategorieë speel by die formulering van eksegetiese teorie. Alhoewel daar 'n bepaalde kenteorie agter ons eksegetiese metode kan bestaan wat rustig die agenda van ons eksegese bepaal, kan dit wees dat ons onder die indruk verkeer dat ons metode, objektiewe eksegetiese resultate sal waarborg wat 'Bybels' en onveranderlik is. Van Huyssteen (1989: 104 ) is deeglik bewus van hierdie probleem as hy opmerk '... the personal involvement of the scientist, and therefore of the paradigm from which he lives and works, always plays a role, not only in the so-called context of discovery, but also in the context of justification.' Hy volg Pannenberg na as hy daarop wys dat wetenskaplike en teologiese uitsprake diep gewortel is in die sosio-kulturele konteks van die individuele navorser (die konteks van ontdekking), maar dat teologiese uitsprake as sodanig (die konteks van regverdiging) indirek gebaseer is op wêreldbeskouings. Hierby wys Van Huyssteen (1989: 111) ook daarop dat sodanige uitsprake ook diepgewortel is in die wetenskaplike se subjektiewe 'religious commitment'.

Ervaring en epistemologiese toepaslikheid - en nie regverdigbare sekerheid nie - maak 'n commitment en gepaardgaande opvattings en aannames geldig en verantwoordelik. Dit impliseer dat die opvattings wat geimpliseer word in 'n commitment in beginsel altyd oop moet wees vir kritiek en impliseer verder 'n hoogs kritiese sensitiwiteit (Van Huyssteen 1989: 114). Hierdie vorm van verbintenis of kontraksluiting geld myns insiens as voorvereiste vir die verstaan van die Ou-Testamentiese 
teks. Dit is myns insiens gepas om 'n onderskeid te tref tussen die lees van 'n teks wat na 'n religieuse werklikheid (God) verwys en die lees van ander tekste.

Van Huyssteen (1987: 14) wil kom van 'n naïewe realisme via 'n positiwisme en instrumentalisme na 'n kritiese realisme. Laasgenoemde erken die belangrikheid van menslike kreatiwiteit in die vorming van teorie en dat daar geen ongeïnterpreteerde toegang tot die werklikheid is nie en dat die rol van die metafoor in die proses van interpretasie sentraal is (Van Huyssteen 1987: 19-20). Dit open voorts ook die weg vir 'n 'faith commitment', terwyl hierdie vorm van realisme pluraliteit, voorwaardelikheid en geldigheid van relevante vorme van kritiek waarborg - so lank die Bybelse teks as 'n religieuse teks gerespekteer word (Van Huyssteen 1987: 21). Kritiese realisme voorsien ons van geldige kriteria vir teologiese geloofwaardigheid en handhaaf juis die gesag van die Bybel.

Dit is belangrik om in hierdie verband daarop te wys dat ' $n$ wysgerige waarheidsopvatting nie staan teenoor 'n Bybelse waarheidsopvatting nie, maar soos Van Huyssteen (1982: 13) treffend aangetoon het dat niemand van ons die voorreg het om die Bybel totaal onbevooroordeeld te benader nie. Hiervan moet ons krities en selfkrities bewus wees. 'Teoretiese vooronderstellinge van een of ander aard maak nie slegs waarneminge moontlik nie, maar determineer ook wat waargeneem word' (Rossouw 1980: 7). So 'n beskouing het twee implikasies: eerstens, dat wetenskaplikes wat van verskillende teoretiese verwysingsraamwerke uitgaan, in werklikheid verskillende verskynsels in sig kry en daarom ook verskillende verskynsels ondersoek; tweedens kom falsifiseerbaarheid van teorieë baie sterk in gedrang, omdat 'n teorie nie afdoende getoets kan word deur gegewens wat self deur die betrokke teorie bepaal word nie (Rossouw 1980: 8).

Bogenoemde lei dan vir Rossouw (1980: 8) tot 'allerlei taktiese sette' wat die wetenskaplike kan uitvoer ten einde afwykende gegewens wat nie inpas by die teoretiese kader waarin hy werk nie, 'akkommodeerbaar te maak'. In hierdie geval wys Rossouw (1980: 8) op die berekende besluit van die wetenskaplike, as strategie, om 'n teorie teen falsifikasie te immuniseer ten einde die positiewe verklaringsmoontlikhede daarvan sistematies te ontgin.

Die implikasies wat wetenskapsteorie vir die eksegetiese metodologie inhou, spreek myns insiens boekdele. Die eerste implikasie verklaar vir ons hoekom verskillende eksegete na 'n teks kan kyk en verskillende elemente van belang gewaar. Dit gee ons ook insig in die verskillende resultate van verskillende eksegetiese metodes vanuit dieselfde teks. Maar dit moet ook ons oë oopmaak daarvoor dat ons nie hewig oor eksegetiese metodologie verskil, terwyl ons in dieselfde kenteoretiese span speel nie. Te veel gebeur dit dat ons die wedstryd van verstaan en interpretasie verloor omdat ons stry oor of elkeen in sy regte nommer 
speel, terwyl ons truie van wetenskapsteorie almal dieselfde lyk.

Die ander implikasie wat uit Rossouw (1980) se opmerkings spruit, is dat eksegetiese metodes wat vanuit verskillende wetenskapsteoretiese vertrekpunte hulle aanvang neem, elkeen binne sy eie epistemologiese raamwerk beoordeel sal moet word. Die hele spektrum van verskillende eksegetiese metodes wat elk opereer vanuit sy wetenskapsteoretiese vertrekpunt sal dan 'n gelyke aanspraak op die teks moet kry, as ons konsekwent wil wees (vgl Loader 1987: 31). Daar kan dan nie net een objektiewe waarheid uit 'n teks wees nie, maar waarskynlik meer as een vorm van waarheid.

\section{EKSEGETIESE METODOLOGIE}

Lategan (1985: 11-12) verklaar onomwonde: 'We only want to draw the methodological conclusion that if the historical and structural elements in biblical texts are seen in terms of a clash between the historical and structural paradigms, and if this is interpreted as necessitating an exclusive choice for either one of these paradigms, we are indeed heading for a hermeneutical cul-de-sac'. Hy meen tereg dat beide die histories-kritiese metode van eksegese en die struktuuranalise as essensiële elemente by die verstaan van 'n teks ter sprake moet kom as kanale van dinamiese interaksie waarlangs 'n kommunikasiebeweging tussen teks en eksegeet plaasvind. Deist (1988: 45) wys op die interessante moontlikheid dat die struktuuranalitiese en krities-historiese metodes van eksegese wat hier te lande soms teen mekaar afgespeel word, afkomstig is van dieselfde wetenskapsteoretiese stal, naamlik die logiese positiwisme (vgl ook Van Huyssteen 1987: 13 in hierdie verband). Met reg vra hy of ses nie dalk vir 'n halfdosyn verruil word deur die twee metodes teenoor mekaar af te speel nie, wetende dat die metodes as leesstrategieë binne dieselfde raamwerk aangewend word?

Daarom oortuig Fryer (1987: 65) ook nie as hy die grammaties-historiese metode van eksegese teenoor die van historiese kritiek stel nie. Met die beperkinge van die historiese kritiek wat hy uitwys, is nie fout te vind nie (vgl Van Huyssteen 1987: 13), maar om aan die ander kant daarteenoor die grammaties-historiese metode voor te hou as: '... this approach is scientific in own right is beyond question: it is in full accord with the self-testimony of the Bible; its presuppositions are in full harmony with claims of Scripture; and its methodology cannot be faulted when judged in the light of its own presuppositions and goals' (Fryer 1987: 66), is myns insiens 'n oorskatting van hierdie metode (vgl ook Fryer 1984: 269). Beide metodes is onderworpe aan subjektiewe vooronderstellings en daarom onderworpe aan kritiek. 'n Inklusiewe benadering (èn ... èn) ten opsigte van verskillende eksegetiese 
metodes is daarom verkieslik bo 'n eksklusiewe ( $\partial \mathrm{f}$... $\partial f$ ) benadering.

Alhoewel kritiek uitgespreek kan word oor die historiese kritiek se hantering van die boodskap (teologie) van Bybelboeke (vgl Swanepoel 1987: 9-15 oor die Forschungsgeschichte van die boek Esegiël) omdat dit meer klem plaas op die wording en groei van 'n teks (vgl Vorster 1987: 379), is die gevaar van die grammatieshistoriese metode weer dat dit a-histories kan neig. Vorster (1987: 380) wys daarop dat die doel van histories-kritiese navorsing saamgevat kan word met die terme verstaan en verklaar 'met die oog daarop om aan te dui hoe ver verwyderd die moderne christen van sy godsdienstige oorspronge staan'. Hierdie vervreemdingseffek tussen toe en nou beoordeel Vorster (1987: 380) positief. Hy wys egter daarop dat onder invloed van teksteorieë uit 'n strukturele en strukturalistiese agtergrond 'die fenomeen teks 'n totaal nuwe epistemiese status begin kry ....' Hiervolgens is die teks nie meer 'n objek wat direk kenbaar is nie en is 'n middelpunt en grense waarvan die betekenis vasstaan vir Vorster (1987: 383) onaanvaarbaar. Hy meen dat lees 'n aktiewe proses van betekenistoekenning is (vgl Gräbe 1987: 7; Vorster 1986: 354, 361) en wys op die belofte wat narratologie, retoriese analises en sosiolinguistiese insigte inhou (vgl ook Lategan 1987: 112-117). Ook Van Huyssteen (1987: 13) vind die werklikheid van die teks, die werklikheid van die leser en die werklikheid van die resepsie van die teks deur die leser van uiterste belang. Om histories te verstaan beteken vir Vorster (1987: 386) om 'n poging aan te wend om 'n fenomeen binne die tyd en omstandighede waaruit dit afkomstig is, te interpretear. In hierdie verband wys hy op die hernieude belangstelling in sosio-historiese aspekte van die wêreld van die Nuwe Testament (dieselfde geld ook myns insiens vir die Ou Testament). Vorster (1987: 387) toon aan dat '... parameters van soort vrae wat gevra mag word, verlê word, nadat dit vir jare vasgevang was in die engtes van die vroëere histories-kritiese navorsing.' Hierdie navorsing sal volgens hom verder bydrae om die afstand tussen toe en nou nog duideliker toe te lig. Hier word 'n bewuste verband gelê tussen teorie en waarneming. 'Die werklikheid wat hier bestudeer word, is nie die 'naakte' mense, 'feite' en dade nie, maar die betekenissamehange tussen die mense, 'feite' en die 'dade' (Vorster 1987: 387).

Wilson (1979: 177) wys op die voordeel van sosiologiese metodes wat 'n wyer keuse van hipoteses vir die betekenis van tekste aanbied. Maar dan herinner Herion (1987: 54) ons ook daaraan dat ook ons historiese rekonstruksies (nes ander metodes van eksegese) onder sterk invloed gebuk gaan van ons wetenskapsteoretiese vooronderstellings. Hy maak in hierdie verband melding van vooronderstellings soos positiwisme, reduksionisme, determinisme en relatiwisme wat elkeen 'n rol kan speel. Daarom is Rogerson (1985: 249) se oproep geregverdig dat wanneer die sosiologiese metode van eksegese gebruik word, aandag gegee moet word 
aan die klemverskille van verskillende skole, en die fout om te dink dat daar slegs een outentieke sosiologie of antropologie is en dat die res negeer kan word, moet vermy word (vgl Swanepoel 1987: 182).

'n Alternatiewe kenteoretiese kader (Deist 1983: 36) soos die ideologie-kritiek hou sowel voordele as nadele in. Met die blote gegewendheid van 'n alternatiewe kenteoretiese kader is geen fout te vind nie (soos elders in hierdie artikel geargumenteer word). Die ideologie-kritiek werp lig op die aanwending van tradisies en wys uit dat die Dawidstradisie(ideologie) verkeerd aangewend kan word sodat dit tot 'n valse ideologie kan ontaard (Deist 1983: 41). Konsekwent toegepas kan ideologie-kritiek egter ook lei tot die devaluasie van sekere ('vals-ideologiese') OuTestamentiese gedeeltes. Hoe sal hierdie betrokke gedeeltes tot hulle reg kom in 'n omvattende Ou-Testamentiese teologie?

Die hermeneutiese vraag word met reg deur Mudge (1980: 1) gevra: 'Is there an intellectually responsible way through the critical sands, always shifting, sometimes abrasive, to an oasis where bedrock, with its springs of water for the spirit, once again appears?' Is ons al verby die woestyn van kritiek, of nog steeds daarin? - 'n vraag wat by meer as een eksegeet bly vassteek. Paul Ricoeur word beskou as teoloog/filosoof wie se denke in die rigting van 'n post-kritiese Bybelse teologie beweeg (Mudge 1980: 2). Sy belangstelling is meer by die finale teks, as by die onderliggende historiese gelaagdheid daarvan. Maar terselfdertyd erken hy: 'I agree that adding a theory of structural reading to the method of historical criticism, as I am now trying to do with biblical narratives, provides only an incomplete answer' (Ricoeur 1980: 44). Om alleen vrae aangaande betekenis te vra en die oor historiese realiteit links te laat, loop volgens hom op 'n mislukking uit. Daarom is sy opvatting dat: '... the world displayed by biblical stories and which shatters our ordinary beliefs about the "real" world, is not a historical world, a world of real events, but the world of the text' (Ricoeur 1980: 44; vgl ook Van Zyl 1987: 52).

Die winspunte van die post-kritiek wat Vorster (1987: 393) uitlig, hou groot voordeel in - nie alleen vir die beoefening van die Nuwe-Testamentiese wetenskap nie, maar myns insiens ook vir die Ou-Testamentiese wetenskap. Daar word 'n hoë premie geplaas deur hierdie nuwe vorm van kritiese wetenskap op geldigheid van uitsprake met betrekking tot kontemporêre opvattings oor teks, geskiedenis, navorsing. Objektiwiteit en waarheid is vir hierdie vorm van wetenskapsbeoefening nie statiese terme wat ewige waarhede moet kondoneer nie. Dit skep ook ruimte vir verbeeldingryke vernuwing terwyl dit nie te make het met restourasie van die histories-kritiese paradigma nie.

Vorster (1987: 375) toon oortuigend aan dat die Nuwe-Testamentiese wetenskap in die rigting van 'n post-kritiese fase van wetenskapsbeoefening beweeg. Dit 
dui vir hom op die periode na die tyd waarin die historiese kritiek en historieskritiese metodes die wetenskap oorheers maar die term het ook '... te make met progressie en met wetenskapsbeskouing, met epistemologie en met beoefening van 'n vakwetenskap. "Krities" staan ook nie teenoor "onkrities" in "post-krities" nie maar wel as 'n nuwe vorm van kritiese wetenskap' (Vorster 1987: 375). Die holistiese paradigma is hier die oorheersende.

Die wetenskaplike wêreldbeskouing waarmee ons na die teks gaan, kan ook maar net 'n 'alternatiewe wêreldbeskouing' in die gedaante van 'n ideologie wees, wat ook maar onkrities in meer as een opsig kan wees (Hawkes 1988: 68). Daarom het ons nodig om nie net die teks nie, maar ook onsself te eksegetiseer. Ons moet ook nie die vrae vergeet wat agter die verhale en simbole van die Ou Testament sluimer nie. Interpretasie behels die herkonstruering van hierdie vrae waarop die teks 'n antwoord wil verskaf. Dit kan ons alleen doen deur na die teks self te gaan.

Terseldertyd sal ons nie uit die oog moet verloor nie dat eksegese moet uitmond in teologiese segggingskrag van 'n teks enersyds, maar andersyds moet dit ook poog om die uiteindelike plek van die individuele teks binne die groter diverse geheel van Ou-Testamentiese teologie aan te toon (vgl ook Snyman 1987: 105). 'n Onlosmaaklike deel van hierdie moeisame weg is dat 'n poging aangewend word om die teologie (lees hoodskap) van 'n teks of tekste (boek/e) vir die hedendaagse mens teologies en aktueel te 'vertaal'. Die teks of tekselemente (simbole) gee tog 'n duiding (teologie $=$ boodskap) ten einde menslike moontlikhede te ontsluit, eksistensiële nood te verlig en lewenskwaliteit te verbeter. Myns insiens maak laasgenoemde 'n onontbeerlike element van Ou-Testamentiese teologie uit.

\section{DIVERSTTEIT IN DIE OU-TESTAMENTIESE TEOLOGIE}

Die simbool (teks of tekselemente) is aanduiding van 'n werklikheid wat 'n menslike moontlikheid kan ontsluit wat andersins nie moontlik is nie (Mudge 1980: 6). Ricoeur (1980: 64) spreek kritiek uit teen Bultmann (alhoewel hy vir ander standpunte van Bultmann groot begrip toon). Hy meen dat Bultmann te min maak van die taal van geloof. Die taal van die Bybel, in sy verskillende literêre vorme, is metafore van inhoud, betekenis en sin vir Ricoeur. Myns insiens is dit een van Ricoeur se besliste winspunte dat hy graag reg wil laat geskied aan die verskillende litirère genres van die Bybel (vgl ook Mudge 1980: 25).

Profetiese literatuur, byvoorbeeld, se openbaring verskil van verhalende openbaring waar die gebeure-Woord element sterk na vore tree. Neem ons nie die verskil in ag waarin die openbaring na ons kom nie, vernou ons verstaan daarvan (Ricoeur 1980: 80). In die geval van die narratiewe vorm van openbaring kan die 
problematiek rondom inspirasie nie die primêre oorweging wees nie, omdat die getuienis aangaande die gebeure langs die weg van die narratief plaasvind. Daarom is die klem op die spoor of getuienis van die gebeure as daad van God (Ricoeur 1980: 79). God maak sy merk in die geskiedenis voordat daaroor gespreek word, maar hierdie geskiedenis word in die taal opgeneem as spreek-daad van die narratief. Die subjektiewe element raak betrokke na die gebeure, maar dit is deel van die vertel. ling soos aangebied aan 'n gemeenskap deur die verteller. Die Woord-gebeure word dus beklemtoon (Ricoeur 1980: 79-80), terwyl die getuigende narratief in kontinuiteit is met die gebeure waaroor getuig word.

Insgelyk het die Tora sy eie openbaringsvorm: 'n geheel van relasies - die relasie tussen die gelowige en die Wet ondergaan 'n transformasie (Ricoeur 1980: 83) as dit ons dade oriënteer en ons instellings belig. Wysheidsliteratuur oorskrei weer op sy beurt die grense wat die Tora nie kan oorsteek nie (Ricoeur 1980: 85), terwyl die himniese genre van die Psalms ook sy eie beklemtonings het (Ricoeur 1980: 88). Die verskillende vorme van die religieuse diskoers is so gelade met betekenis, sodat 'n eenvormige en monotone formulering van openbaring net nie meer kan geld as ons wil praat van Bybelse openbaring nie (Ricoeur 1980: 92).

Dit word dus duidelik dat die vorm van openbaring bepaal word deur die diversiteit van die literatuur waarmee ons te doen het. Dit is ook om hierdie rede wat daar al meer stemme (Hasel 1982: 94, 178-179; Prinsloo 1987: 39; Snyman 1987: 104; Goldingay 1987: 39) opgaan wat vra vir die erkenning van die diversiteit van die Ou Testament. Veral waar die skryf van een Ou-Testamentiese teologie (teologie in die sin van die boodskap van die Ou Testament vir vandag) ter sprake kom, word daar gepleit deur Bybelwetenskaplikes dat daar verskillende teologieë in die Ou Testament is, en dat die teks toegelaat moet word om self sy teologie na vore te laat kom. Vosloo (1987: 89) wys op 'n belangrike aspek omtrent die diversiteit wat nie verontagsaam kan word nie: 'Daar sal nie net gevra moet word na wat elke afsonderlike eenheid sê nie, maar ook hoedanig die verhouding tot die teologie van ander eenhede is, veral wanneer daar kontrasterende teologiese beskouings na vore kom. Daarby sal daar rekening gehou moet word met die groeiproses binne-in die betrokke eenheid.'

Alhoewel 'n historiese benadering tot interpretasie voorveronderstel dat ons dokumente in terme van hulle betekenis in historiese konteks as kommunikasie tussen 'n skrywer en sy lesers verstaan, sluit hierdie benadering nie uit dat 'n diversiteit van blikpunte saamgevat kan word in 'n groter geheel (soos die Ou Testament) nie (Goldingay 1987: 26). Dit geld ten spyte van die feit dat hierdie groter samehang nie sy ontstaan vanuit die oorspronklike historiese oorweging by die totstandkoming van 'n bepaalde onderdeel (boek) gehad het nie. Daarmee 
saam is dit my oortuiging dat ons nie teenoorstaande perspektiewe in tekste en teologieë moet probeer harmonieer en versoen, indien die teks nie self leidrade in hierdie rigting verskaf nie. Die groot opgawe vir Ou-Testamentiese teologie bly om die teologiese eenheid van die Ou Testament vas te stel sonder om die teologiese diversiteit prys te gee (Goldingay 1987: 28). Wie die diversiteit prysgee, gee tot 'n groot mate die aktualiteit van die Ou Testament prys. Ricoeur (1980: 92) is ten regte van mening dat die openbaringsgesag dan in die gedrang kan kom.

Goldingay (1987: 37) pak die moeisame taak aan op weg na én Ou-Testamentiese teologie. Eerstens ondersoek hy die kontekstuele of historiese benadering. Die klem val gevolglik op konteks as sleutel vir hedendaagse verstaan. Historiese verstaan impliseer beide teks en die moderne situasie. Hy wys ten regte daarop dat ons nie altyd die omstandighede ken waarin die teks ontstaan het nie. Dit kan aanleiding gee tot is-gelyk-aan-tekens tussen die Bybelboodskap en die moderne situasie. 'n Ander probleem is dat sommige Ou-Testamentiese perspektiewe vir ons meer normatief as ander perspektiewe kan wees. Goldingay worstel met vrae soos: Op watter gronde kies ons vir een perspektief bo 'n ander? Die trajekmodel van J M Robinson word deur Goldingay (1987: 40) gebruik om die historiese benadering te belig. Ook $\mathrm{H}$ Gese is een van die eksponente van hierdie model. Die doel van hierdie model is om die teologie van bane of trajekte vas te stel (Traditionsgeschichte) aan die hand van temas soos land of verbond of wet. Die historiese realiteit is in die beweging geleë (Goldingay 1987: 40). Hiervolgens is die hele verstaan van die Ou Testament in die verstaan van die trajek van 'n bepaalde tradisie geleë - dit is 'n voortsettting van die traditionsgeschichtliche benadering van Gerhard von Rad (vgl ook Pannenberg 1967: 86-88).

'n Problematiese punt vir my in die benadering van Goldingay (1987: 42) is dat sommige punte op die baan van beweging volgens hom meer teologies relevant is as ander punte. Dit is na my mening moeilik om in te sien hoe bepaal gaan word watter fase van die betrokke tradisie teologies die mees relevante is. Dat die verskillende teologiese tradisies verskillende teologiese momente saamdra, staan vas. Daar kan egter na my mening kritiek ingebring word teen die keuse van een bepaalde tradisie-moment bo 'n ander op die tradisie-trajek. En dan bly die vraag ook nog staan oor die wysheidsliteratuur asook die apokaliptiek wat nie tradisies (in die eng sin van die woord) bevat nie: Is hierdie tipe literatuur dan teologies minder relevant? Daar moet met Goldingay (1987: 48-54) saamgestem word as hy ten opsigte van die verhouding tussen Goddelike en menslike aktiwiteit daarop wys dat by verskillende punte op die trajek die verhouding in verskillende vorme na vore tree.

Die tweede benadering wat Goldingay (1987: 118) ondersoek, noem hy die evaluerende of kritiese benadering. Hierdie benadering wil die teks kritiseer vanuit 
die moderne bewussyn. Hierdie werklikheid moet geëvalueer word in die lig van die werklikheid van die eksegeet. Die interpreut is nie net begaan oor die outeur van die teks nie, maar veral om getrou te wees aan die saak (hy verstaan dit dalk beter as die outeur). Volgens Goldingay (1987: 119) vertel die interpreut ons nie net wat die outeur bedoel het (onderskei van wat hy geskryf het) nie, maar ook wat hy veronderstel was om te bedoel teenoor wat hy bedoel het. Dit is dan ook die verskil tussen Barth en Bultmann vir Goldingay (1987: 120): 'For Barth, our own meeting with God is a means of understanding scripture, for Bultmann it is a means of evaluating scripture.'

Dit is vir my van wesenlike belang dat daar ook 'n positiewe evaluasie gegee word van die materiaal wat as van 'minder teologiese belang' beskou word (vgl ook Goldingay 1987: 131). Hier moet ons aansluit by Ricoeur wat meen dat ons agter Bybelse materiaaal moet inkyk (op voetspoor van Gadamer) ten einde die egte waarheid te ontbloot wat verskuil is agter rasionaliserings. Die kritiese benadering moet die eksegeet in staat stel om verby die naiwiteit van 'n oppervlakte lesing van die teks te beweeg. Hierdie naiwiteit kan nog nie die egte boodskap onderskei van die verwysingsraamwerk van werklikheidswaardeskale wat kultuur, dogma en konfessionele bande verskaf nie (Mudge 1980: 23). Deur te beweeg tussen 'n hermeneutiek van suspisie en een van herontdekking kom die eksegeet verby die eerste naïwiteit uit by 'n tweede naiwiteit (Ricoeur). Hierdie tweede naïwiteit maak dit moontlik om die teks te hoor as 'n geheel en op 'n oop wyse. Dit is egter postkrities en nie pre-krities nie; 'n ingeligte naliwiteit (Goldingay 1987: 132). Post-kritiese naiwiteit bring die positiewe betekenis aan die lig van materiaaal wat van mindere waarde is. Goldingay (1987: 133) meen dat 'n post-kritiese ingesteldheid dit moontlik maak vir die teks om ook ons wêreldbeskouing te bevraagteken. So 'n persepsie van die teks is oop tot meervlakkige lesings - iets wat vereis word deur simboliese of poëtiese uitsprake oor realiteite (God) dieper as die materiaal self.

Dit lyk vir my dat 'n swakplek in Goldingay (1987: 167) se metodologiese ontwerp geleë is in die derde benadering wat hy volg in die proses om 'n OuTestamentiese teologie te konstrueer, naamlik die eenheids- of konstruktiewe benadering. Hierdie benadering is grootliks gebaseer op die 'cross-section' metode van Eichrodt - vir wie Goldingay (1987: 168) groot waardering het. Alhoewel hy ook groot waardering vir Von Rad het, meen hy tog dat Eichrodt verder gaan as Von Rad deur sy sistematise-rende konsep van Ou-Testamentiese teologie (Goldingay 1987: 173). Dit is in hierdie verband opvallend dat Goldingay, wat juis wil wegbeweeg van dogmatiese konsepte wat van buite af ingedra word in die OuTestamentiese teologie self, ook maar die prooi daarvan word want Eichrodt gebruik ook maar sistematiese konsepte (die verhond) om sy Ou-Testamentiese 
teologie te orden rondom God-Israel, God-wêreld en God-mens.

Simbole funksioneer as teologiese aanduiders (vgl ook Goldingay 1987: 174). Simbole neem deel aan die krag waarheen hulle verwys. Simbolisme het 'n geheel, holistiese benadering en probeer verbande lè. 'n Voorbeeld hiervan is vir Goldingay (1987: 175) die verbond. 'n Simbool is 'open-ended' in die sin van 'n gelykenis en het die hermeneutiese openheid van 'n spreuk en bied geen klaargemaakte interpretasie nie en plaas ook nie beperkinge op die intuïsie nie. Goldingay (1987: 176) volg in hierdie verband die gedagtes van Ricoeur. Die taak van Bybelse teologie behels dus die inagneming van die kenmerkende dinamiek van simbolisme asook om reg te laat geskied aan die spesifieke aard daarvan in 'n proses van ontginning van die moontlikhede in konsepte wat vir ons bevatlik is. Die vertaling van simbole in teologiese terme is 'n risiko wat misverstaan tot gevolg kan hê. Die begrip verbond is myns insiens hiervan 'n goeie voorbeeld. Die dogmatiek praat van 'verbond', maar Bybelwetenskaplikes vra met reg: 'watter verbond?' - want daar is meer as een verbond in die Ou Testament om nie eers te praat van die verskille tussen elkeen nie.

Ten slotte moet die taak van Ou-Testamentiese teologie na my mening gesien word as 'n konstruktiewe taak wat nie is om al die (teologiese) blokke af te skaaf tot dieselfde grootte nie, maar dit te gebruik in die verskeidenheid van vorme (vgl ook Fensham 1985: 254). Goldingay (1987: 185) meen daarom ook met reg dat die taak van Ou-Testamentiese teologie nie bloot deskriptief kan wees nie: 'OT theology, in particular, then, is naturally concerned to analyze and articulate insight from the OT which remains significant for humanity'. Daar moet met Goldingay (1987) saamgestem word dat daar ruimte vir meer as een benadering moet wees in die samestelling van 'n Ou-Testamentiese teologie. Dit is hierdie winspunte van Goldingay wat ten spyte van kritiek wat op baie punte teen sy Ou-Testamentiese teologie ingebring kan word, sy boek 'n uiters positiewe bydrae maak op die weg na 'n OuTestamentiese teologie.

\section{WOORD-GEBEURE OF GEBEURE-WOORD?}

Dit is betekenisvol om te verneem van die invloed wat Gerhard von Rad op Ricoeur se denke uitoefen (Mudge 1980: 22). Daarom is dit ook nie vreemd om die tweeling van Ou-Testamentiese denke, naamlik gebeure en woord, 'event and meaning' by Ricoeur se kategorieë van interpretasie aan te tref nie - hy plaas die gebeure eerste en die interpretasie daarvan telkens tweede. Gunneweg (1978: 192, 199-201) en Hawkes (1988: 63) verkies weer die omgekeerde volgorde Woord-gebeure, met ander woorde die teks is daar ter wille van die Woord-gebeure (vgl ook Boshoff 
1987: 371; Fensham 1985: 253). Volgens die gebeure-Woord volgorde is'die oorsprong van geloof histories, maar die verstaan daarvan '... a matter of "recreating the intellectual activity born of this historical faith"' (Mudge 1980: 22). Dit is dus duidelik dat Ricoeur ten regte nie die eenheid gebeure-Woord, feit-interpretasie wil loslaat nie, alhoewel hy sterk klem wil lê op die taal/woord/metafoor aspek. Ons bestaan myns insiens omdat ons gevorm word deur gebeure of soos Ricoeur (1980: 114) dit stel: 'the event is our master'. Ons is absoluut afhanklik van sekere grondgebeure. Dit is gebeure wat nie vergaan nie, maar voortduur en daarom is daar gebeure-tekens. Om onsself te verstaan moet ons identifiseer daarmee. Ook ander denkers soos Wolfhart Pannenberg vind in die eenheid van woord en gebeure aansluiting by Von Rad.

Dit is nie toevallig dat die Ou-Testamentiese navorsing die gedagte van Geschichte in die teologie beklemtoon nie. Pannenberg (1967: 84) wys met reg daarop dat Von Rad se metode nog veel meer belofte in die deurvoering daarvan toon as wat die programmatiese formulering daarvan suggereer. Von Rad werk nie met die histo-ries-kritiese weergawe van Israel se geskiedenis nie, maar met Israel se eie verstaan van hierdie Heilsgeschichte van Jahwe met Israel (Pannenberg 1967: 85). Hy waarsku daarteen dat die werklike geskiedenis van Israel ook nie verwaarloos moet word nie. Vir Von Rad gaan dit egter om historiese verstaan. Dit behels onder meer dat ons nie met ons historiese beeld van die geskiedenis van Israel (wat dit ook al sou wees), oor die Geschichtszeugnisse Israel selbst oor heen moet gaan nie.

Dit behels onder andere dat fyn gekyk moet word na die proses van tradisievorming (Westermann 1974: 73; Venter 1987: 762), omdat alles sin en betekenis hier rondom verkry (Pannenberg 1967: 86). In die proses van tradisievorming tree die eenheid van Geschichte und Geschichtsbewusstseins ans Licht. Die winspunt van Von Rad wat Pannenberg (1967: 87) aantoon, is dat hy die teologiese substansie van die Heilsgeschichtliche Theologie nie verlore laat gaan nie. Die kerugmatiese karakter van die Traditionsgeschichte kom langs hierdie weg tot sy reg. Von Rad maak die moontlikheid van 'n biblischen Theologie sigbaar (Pannenberg 1967: 88).

Wanneer Pannenberg se benadering konsekwent toegepas word deur onder andere Stuhlmacher en Gese verander sola Scriptura in sola historia (vgl Gunneweg 1978: 192). Dit veronderstel dan 'n oop kanon wat vrae laat ontstaan oor die rol van Bybelgeskrifte in die vasstel van 'n Ou-Testamentiese teologie. Gunneweg (1978: 199) meen ten regte ook dat die eksegetiese basis van Pannenberg se ontwerp baie dun en onbevredigend is. Hy verkies Zimmerli wat die klem swaarder op die Woord as 'n gebeure wil laat val (Gunneweg 1978: 200). Maar die standhoudendste kritiek teen Pannenberg kan na my mening ingebring word teen die beklemtoning 
van tradisie-geskiedenis as ontwerp vir 'n teologie. Dat hierdie vorm van teologisering ' $n$ belangrike plek moet kry in die skryf van 'n Ou-Testamentiese teologie, het Von Rad reeds onbetwisbaar bewys. Maar selfs Von Rad het ook sy probleme met literatuur gehad wat nie tradisies bevat nie (soos die wysheidsliteratuur en apokaliptiek) in die ontwerp van sy teologie. Daarom sal Ou-Testamentiese teologie meer omvattend en ruimer as 'n teologie van tradisie-geskiedenis moet wees.

Dit lyk vir my dat daar vir beide beklemtonings naamlik Woord-gebeure en gebeure-Woord plek moet wees binne die raamwerk van Ou-Testamentiese teologie. Albei opvattings kan tuisgebring word onder die noemer van 'n ruimer historiese verstaan, 'n post-kritiese verstaan (teenoor fundamentalisme). So 'n historiese verstaan omvat die kloof tussen Woord en gebeure as deel van 'n groter holistiese geheel. Dit is een van die winspunte van Pannenberg (1967) se universalgeschichtliche benadering vir die Ou-Testamentiese teologie.

\section{HOE KAN DIE PROBLEEM TUSSEN TOE EN NOU OORBRUG WORD?}

Die kloof wat daar bestaan tussen feit en betekenis, tussen Historie und Kerugma, tussen die historiese Jesus en die getuienisse aangaande Hom is enersyds die probleem van hedendaagse teologie (Pannenberg 1967: 16). Ook Ricoeur (1980: 145) worstel met hierdie probleem as hy geen skeiding bepleit tussen die historiese Jesus en die Christus van die geloof nie - die eenheid staan volgens hom geskryf: Jesus-Christus. Andersyds bestaan die probleem van die kloof tussen die denkwêreld van die Nuwe Testamentiese teks en ons denkwèreld vandag. Myns insiens geld hierdie problematiek ook ten opsigte van die Ou Testament. Die een kant van die probleem met die Ou Testament is die spanning tussen gebeurtenis en die Woord daaroor. Die ander probleem is die wêreldbeeld van die Ou Testament wat van vandag se wèreldbeeld verskil. Die antwoord wat Pannenberg (1967: 17) langs die weg van Gadamer verskaf, kan na my mening ook lig werp op Ou Testamentiese problematiek.

Hoe kan die afstand tussen die teks en die vandag van die eksegeet oorbrug word? Prinsloo (1987: 38) toon ten regte aan dat Stendahl se onderskeid tussen 'what it meant' en 'what it means' net nie meer haalbaar is nie. Die antwoord hierop is vir Gadamer deur die versmelting van horisonne (Pannenberg 1967: 17). Hierdie is myns insiens ' $n$ belangrike gesigspunt in die soeke na oplossings vir hermeneutiese probleme. Die begripshorison van die eksegeet moet verbreed sodat dit die verstaanshorison van die teks kan omvat. Sodanige horisonsversmelting oorbrug die afstand tussen toe en nou sonder om dit te verwyder. Die hermeneutiese probleem moet op 'n wyse oorbrug word wat die Geschichte van die oorgelewerde teks en van 
vandag bewaar en ophef (Pannenberg 1967: 118). Maar hoe kry die eksegeet en die teks so 'n gesamentlike horison? Ek meen dat hierdie vraag met behulp van die Universalgeschichte beantwoord kan word (vgl Pannenberg 1967: 19).

Hierdie denke het sy ontstaan uit die Bybelse nadenke oor God. Die God van die Bybel kan dit moontlik maak om die totaliteit van die werklikheid as Geschichte, as nuwer en eenmaliger gebeure afgestem op 'n finale doel te verstaan. Daar is ooreenstemming in die wyse waarop die hermeneutiek en die Universalgeschichte vir Pannenberg (1967: 93) funksioneer. Beide werk met die teks. Beide bereik vandag met behulp van die teks. Daar is egter een belangrike verskil: die hermeneutiek (vir Pannenberg) beweeg slegs tussen die toe van die teks en vandag van die eksegeet terwyl die Universalgeschichte agter die teks probeer inkom en soek na die vrae wat geleë is agter die gebeure wat aanleiding tot die teks gee. Hier word gesoek na die Universalgeschichtliche betekenissamehang met die oog op vandag. Hierdie universeelhistoriese betragting word sodoende 'n omweg na die gebeure wat aanleiding gegee het tot die teks, met die doel om langs hierdie omweg die brug tussen toe en nou verstaanbaar oor te steek.

Myns insiens verbreed die Universalgeschichte die hermeneutiese proses op so 'n wyse dat dit moontlik word dat voorvrae ook op die tafel beland. Pannenberg (1967: 93) dui met reg aan dat die saak waaroor die teks spreek, nie altyd 'n gebeurtenis is nie. 'n Teks kan ook 'n matematiese waarheid, 'n natuurverskynsel, 'n tegniese raamwerk of 'n filosofiese gedagte wees. By Bybeltekste het ons egter te doen met getuienisse aangaande bepaalde gebeure en wat gevolglik innewohenden betekenis behels - die terugvra agter hierdie gebeure vra na die werklike gebeure en is daarom histories. Dit is van groot belang dat die kontinuïteit tussen werklike gebeure (feit) en die gebeure van die teks (duiding) gehandhaaf word.

Maar die Universalgeschichte gaan ook verder want dit maak enersyds die begrensdheid van menslike ervaring duidelik en andersyds bring dit 'n openheid na die toekoms (Pannenberg 1967: 121). In die historiese Jesus word die eindgebeure geantisipeer - dit leer die Universalgeschichte ons. Vir die doel van hierdie studie impliseer die Universalgeschichte nie dat die Ou Testament Christosentries verstaan moet word nie, maar gaan dit om die toepassing van die universalgeschichtliche metode van Pannenberg op Ou-Testamentiese hermeneutiese probleme. Die Universalgeschichte verruim myns insiens die verstaan van oorgelewerde tekste. Langs hierdie weg word bemiddeling bewerkstellig tussen die toe van die teks en die nou van die eksegeet. Die teologie van die teks tree na vore en spreek die mens in die hart van sy hedendaagse bestaan aan. Die openheid na die toekoms open moontlikhede vir die verstaan en handelinge van die hede. Pannenberg (1967: 122) wys ons in hierdie verband daarop dat die betekenis van Gadamer daarin geleë is dat daar 
bemiddeling tussen die toe van die teks en nou van die eksegeet bewerkstellig word.

Dit is egter per slot van rekening net God wat van geskiedenis ('history') teologie ('His-story') kan maak. Die Ou Testament stel Jahwe aan mense bekend ten einde ons eie geskiedenis merkbaar (teo-logies) te beïnvloed. Ons moet versigtig wees om nie 'n garstige Grabe tussen ons en die teks te skep nie (Deist 1987: 12). Hy meen ten regte dat ons meer histories (Deist 1979: 28-29) moet dink en nie historisties nie (Deist 1987: 13). Jahwe openbaar Homself in dade en in prosesse, maar nie alleen in die geskiedenis nie, ook in die natuur - sy skepping. Sy teenwoordigheid neem meer as een vorm aan. In sy Naam is die kontinuïteit van die Ou Testament geleë (Zimmerli 1972: 15). Sy woorde laat gebeurtenisse plaasvind. Daarom sal die skryf van 'n Ou-Testamentiese teologie histories moet wees omdat teks sowel as OuTestamentikus albei deel is van die geskiedenis en dus ook van 'n voortdurende proses van interpretasie en herinterpretasie (Le Roux 1987: 71).

Aan die een kant moet so 'n historiese verstaan die verskil tussen die wêreld van die Ou Testament en die wêreld van vandag respekteer. Aan die ander kant is histories dus hier in 'n ruimer sin te verstaan wat die kloof tussen toe en nou in 'n sekere sin oorbrug en ruimte laat vir die verskillende (ook buite die tradisiehistoriese) werksaamhede en dinamiese aktiwiteite van Jahwe (vgl Westermann 1978: 6), wat ook vandag in ons wèreld voortgesit kan word. Die Ou-Testamentiese teologie het die taak om reg te laat geskied aan wat die Ou Testament in al sy dele aangaande God getuig. Hiertoe kom die Ou-Testamentiese teologie nie sonder die wisselwerking tussen teks, eksegetiese metodologie en wetenskapsteorie nie.

\section{Literatuurverwysings}

BOSHOFF, PB 1987. Eksistensiale verstaan van die Ou Testament: Die teologiese arbeid van Antonius HJ Gunneweg. HTS 43, 357-373.

DEIST, FE 1979. Historiese heuristiek, teologiese hermeneutiek en Skrifgesag. Port Elizabeth: Universiteit van Port Elizabeth. (Navorsingspublikasie C11.)

DEIST, FE 1983. Bibelinterpretation und/als Ideologiekritik. OTE 1, 26-48.

DEIST, FE 1987. Relatiwisme en absolutisme: Kan dit oorkom word? Oor 'Bybelse' en 'dogmatiese' teologie, in Prinsloo \& Vosloo 1987: 1-17.

DEIST, FE 1988. 'Gekontroleerde' eksegese en/of 'kreatiewe' uitleg. HTS 44, 3954.

FENSHAM, FC 1985. Die verhoudingsteologie as 'n moontlike oplossing vir 'n teologie van die Ou Testament. NGTT 26/3, 246-259.

FRYER, NSL 1984. The freedom of the exegesis. NGTT 25/3, 260-269.

FRYER, NSL 1987. The historical-critical method - yes or no? Scriptura 20, 41-70. 
GOLDINGAY, J 1987. Theological diversity and the authority of the Old Testament. Grand Rapids: Eerdmans.

GRäBE, I 1987. Methodological points of departure in the reading of texts. OTE S, $1-8$.

HASEL, G 1982. Old Testament theology: Basic issues in the current debate. 3rd ed. Grand Rapids: Eerdmans.

HAWKES, G 1988. Beyond criticism: Bible study today. Journal of theology for Southem Africa 65, 60-72.

HERION, GA 1987. Sociological and anthropological methods in Old Testament study. OTE 5, 43-64.

LATEGAN, BC 1985. Some unresolved methodological issues in New Testament hermeneutics, in Lategan 1985: 3-26.

LATEGAN, BC \& VORSTER, WS 1985. Text and reality: Aspects of reference in biblical texts. Philadelphia: Scholars Press. (SBL Semeic Studies.)

LATEGAN, BC 1987. Inleidende opmerkings oor resepsieteorie en die uitleg van Bybelse materiaal. NGTT 28/2, 112-117.

LE ROUX, JH 1987. Die verhouding tussen Ou Testament teologie en die geskiedenis van Israel, in Prinsloo \& Vosloo 1987: 67-74.

LOADER, JA 1987. Interpreting the Old Testament in South Africa exegesis, meaning and social relevance. OTE 5, 24-31.

MUDGE, LS (ed) 1980. Essays on Biblical interpretation. Philadelphia: Fortress.

PANNENBERG, W 1967. Grundfragen systematischer Theologie. Göttingen: Vandenhoeck.

PRINSLOO, WS 1986. Die gesag van die Ou Testament: 'n Praktiese illustrasie uit Joël 2: 12-17. NGTT 27/4, 410-416.

PRINSLOO, WS \& VOSLOO, W 1987. Ou Testament teologie: Gister, vandag en môre. Pretoria: NG Kerkboekhandel. (UPTS 4.)

PRINSLOO, WS 1987. Ou Testament teologie vandag, in Prinsloo \& Vosloo 1987: 29-46.

RICOEUR, P 1980. Preface to Bultmann, in Mudge 1980: 49-72.

RICOEUR, P 1980. Toward a hermeneutic of the idea of revelation, in Mudge 1980: 73-118.

RICOEUR, P 1980. The hermeneutics of testimony, in Mudge 1980: 119-154.

ROGERSON, JW 1985. The use of sociology in Old Testament studies, in Emerton, J A (ed), Supplementto VT Vol 36: Congress volume Salamanca 1983. 245-256. Leiden: Brill.

ROSSOUW, HW 1980. Wetenskap, interpretasie, wysheid. Port Elizabeth: Universiteit van Port Elizabeth. (B7.) 
SNYMAN, SD 1987. Die verhouding tussen Ou Testament teologie en Ou Testament eksegese, in Prinsloo \& Vosloo 1987: 95-106.

SWANEPOEL, MG 1987. Die teologie van Esegiël 33 tot 39. Ongepubliseerde DD-proefskrif, Universiteit van Pretoria.

VAN HUYSSTEEN, JWV \& DU TOIT, BJ 1982. Geloof en skrifgesag. Pretoria: NG Kerkboekhandel.

VAN HUYSSTEEN, JWV 1987. Understanding relıgious texts: The role of models in biblical interpretation. OTE 5, 9-23.

VAN HUYSSTEEN, JWV 1989. Truth and commitment in theology and science: An appraisal of Wolfhart Pannenberg's perspective. HTS 45, 99-116.

VAN ZYL, HC 1987. Spektrum. Fax Theologica 7/1, 50-52.

VENTER, PM 1987. Die kanonbegrip as Bybels-teologiese probleem. HTS 43, 755-768.

VORSTER, WS 1986. Readings, readers and the succession narrative: An essay on reception. ZAW 98, 351-362.

VORSTER, WS 1987. Op weg na 'n post-kritiese Nuwe-Testamentiese wetenskap. HTS 43, 374-394.

VOSLOO, W 1987. Die verhouding tussen Ou Testament teologie en inleiding, in Vosloo \& Prinsioo 1987: 75-94.

WESTERMANN, C 1974. Forschung am Alten Testament. Gesammelte Studien 2. München: Kaiser.

WESTERMANN, C 1974. Das hermeneutische Problem in der Theologie, in Westermann 1974: 68-83.

WESTERMANN, C 1978. Theologie des Alten Testaments in Grundzügen. Göttingen: Vandenhoeck.

WILSON, RR 1979. Anthropology and the study of the Old Testament. Union Seminary Quarterly Review 34/3, 175-181.

ZIMMERLI, W 1972. Grundriss der alttestamentlichen Theologie, 4. Aufl. Stuttgart: Kohlhammer. 